\title{
The Implication of Traditional Chinese Culture in Peking Opera
}

\author{
Moqiao Liu \\ RDFZ Xishan School, Beijing, 100193, China \\ emichelle@163.com
}

\begin{abstract}
Beijing Opera, as a national opera, is also a part of Chinese traditional culture, is an important form of traditional Chinese culture. It not only shows the characteristics of Chinese traditional culture, but also contains fine traditional virtues and spiritual thoughts. In order to spread the Chinese culture like Peking Opera from generation to generation and promote its international spread, this paper aims to explore the characteristics and implications of traditional Chinese culture embodied in Peking Opera.
\end{abstract}

Keywords: Beijing Opera; Chinese Traditional Culture; Chinese Cultural Elements.

\section{Introduction}

Beijing Opera is one of the most influential forms of Chinese opera. With Beijing as the center, it is distributed all over the country, so it is called "Beijing Opera". In Qing Dynasty, four Huizhou classes entered Beijing, and Peking Opera entered Beijing from then on. It not only combined some plays, tunes and performance methods of Kunqu Opera and Qinqiang Opera, but also absorbed some folk tunes [5]. Through constant communication, fusion and innovation, Beijing Opera finally formed. Beijing Opera is mainly divided into four roles: sheng, Dan, Jing and Chou, and four skills: singing, reading, playing and Wushu.

\section{The Chinese Cultural Elements of Peking Opera}

The main body of Peking Opera performance is the Peking Opera actor. Peking Opera actors with different roles wear different costumes, different headdresses, and different facial makeup in order to accurately represent their roles and fully express their emotions. The dress and headdress of Peking Opera complement each other. The emperor and the dignitaries were all dressed in boa constrictors, wearing the Pingtian crown and the Phoenix crown [4]. By the clothes of generals who lead armies into battle. For example, when Mu Guiying was in charge of the army, the female generals of the Yang family were dressed in such costumes to lead soldiers into battle. Swordsmen and heroes usually wear a cap. Pleats are the casual clothes commonly used by some scholars. The ladies of large families generally have hairpin flowers, showing a lively and lovely character, which the audience will know at a glance. These waiting-women's costumes are mainly flowers and butterflies, which are more light and flexible, such as the butterflies in the clothes of the small matchmaker in the Peking Opera "Matchmaker". And the boudoir and the waitresses dress to show the lively different, they are more dignified and generous, fresh and elegant, dress color is mostly light green, blue, lotus, and so on, showing a small collar. Their makeup look also does not have so warm, more qingli free from vulgarity [4]. Beijing Opera also shows the symmetry characteristic of Chinese classical aesthetic, showing the beauty of modesty. In addition, figures of different classes also wear different clothes, fully showing the ancient Chinese hierarchy. The costumes of Peking Opera also show the changes of the characters, and the facial makeup and makeup show different ages and states. A facial mask is a mask painted with brushes and paint to reflect the characteristics of a character. Facial makeup usually has red, black, white, green, blue, yellow, pink and ash. Red represents loyalty, and white represents the crafty sycophants, and usually the face of clowns is mainly white. Black represents virtue and justice, which reminds us of Zhang Fei's loyalty to the country during The Three Kingdoms. For example, guan Yu's silk eyebrows, phoenix eyes, and the two white eyebrows on Huang Gai's facial makeup are reflected by the swordsman leading the army to fight $[2,4]$. Therefore, clothing and 
facial makeup not only show the design concept of China, but also fully show the traditional values and virtues advocated, good and evil. They are the carrier of roles and the reflection of culture.

Peking Opera actors do not just dress up to express their roles. They use a variety of singing styles, which are coordinated with props, sets and performing instruments on stage to express the strong emotions of their roles in an all-round way [6]. We can feel the musical rhythm of Peking Opera through the singing of the actors. Different singing styles of actors also presents different roles. For example, the role performers in the songs "Selling Water" and "Matchmaker" are all playing the role of young girls in the songs. Their singing styles are graceful and beautiful, which is also the most prominent singing styles of The Actresses. The performance of the performers in Qing Yi is all ladylike, and their singing is all mellow and profound. The movements of the actors and their singing are complementary to each other [7]. They will use blue fingers, fengtou fist and circle field to coordinate with their singing content. Among them, the orchid, as one of the four gentlemen of flowers, also reflects the traditional Chinese culture. Another example is to hold the chin, and the pointing of the finger indicates that the audience is looking at the person or object in the opposite direction, which enables the audience to better understand their performance and shows the beauty of the scene. They also played the erhu as an accompaniment to assist the performers in singing. Erhu is also a traditional Chinese musical instrument, which reflects the profound influence of Chinese culture and can be integrated with different arts, reflecting the harmonious beauty. The props in the performance, as the actor's "second hand", vividly show the character image. For example, in The Empty City Plan, Zhuge Liang holds the feather gauze and gently shakes it to sing, which makes the character image alive instantly. Some props are also used throughout the performance, such as a handkerchief used by a woman to convey emotion. The seating arrangement also shows a kind of symmetry. Some characteristics of traditional Chinese culture are also contained in the design of props.

Only with the lyrics and story content of the performance can the Peking Opera actors perform a moving performance. The materials of Peking Opera mainly come from three aspects. First, there are historical stories. Most of them take famous historical figures as the protagonists, and the stories are based on the deeds of historical tasks, such as farewell to my concubine, swimming in all rivers, and changing the crown prince for the leopard cat. The love between $\mathrm{Yu}$ Ji and $\mathrm{Xiang} \mathrm{Yu}$ is heartwrenching. When Xiang Yu was defeated on all sides, Yu Ji did not want to cause Xiang Yu to cut her throat, which showed the love between $\mathrm{Yu}$ Ji and Xiang Yu, and reflected the delicate feelings of the hero. There are "You Hundred Rivers" show the patriotic spirit, "leopard cat for prince" show the good traditional Chinese virtues. The legend is especially based on the foundation of Chinese culture. In the Peking Opera "FairiesScatter Flowers", the dance of "Fairies Scatter Flowers" is derived from the Dunhuang apsaras, a god in Chinese mythology [3]. It can be seen that Chinese culture has permeated the performing art of Peking Opera in many ways.

\section{The Implication of Traditional Chinese Culture}

As a part of traditional Chinese culture, Peking Opera shows many elements of traditional Chinese culture. The most common traditional cultural instrument in Peking Opera is the fan. Fans can not only depict characters' personalities, but also assist actors in singing and acting. Peking Opera performers usually smile when they sing, because the fan's expansion shows the performer's broad heart, so it is common for officials in the performance to hold an expanded fan. In the process of performance, the fan usually unfolds, covers, lifts, turns, and closes, sometimes showing the shy emotion of the woman, sometimes showing the signs of plot transformation [4]. Peking Opera also contains some traditional culture of qin, chess, painting and calligraphy. The two protagonists of the show usually paint together when they fall in love, drawing bamboo to show their love. As the four gentlemen among the flowers, bamboo shows the strong, brave and indomitable qualities of the Chinese people. Both men and women use the four treasures of the study (pen, ink, paper and inkstone) when they convey their feelings [4]. They sometimes use ink to write letters to express their missing. 
As a part of traditional Chinese culture, Peking Opera also shows many other elements of traditional Chinese culture.

Beijing Opera not only shows many elements of traditional culture, but also contains the unforgettable Chinese spirit. This brings Peking Opera closer to people's lives and shows the great and sincere emotion and spirit of the Chinese nation [7]. For example, in the story of the Yang family, the song mu Guiying is the Master, which shows the scene of Yang Wenguang, Yang Jinhua's mother $\mathrm{Mu}$ Guiying, leading soldiers to prepare for the war. At that time, when the Western Xia invaded the Central Plains, Yang Wenguang won the command in a tournament and handed him over to his mother, hoping that she would go to defend the country. Although the Yang family and the emperor had some misunderstanding and bad blood, but the old lady to see the military, for the people for the country to want to protect the country. She was once the Yang family female to persuade Mu Guiying to fight, Mu Guiying also think that grandma is right, he also put down the past and the emperor's bad blood, resolutely decided to fight. Embodies the Yang family female general loyal army patriotic spirit [3]. Peking Opera shows this dedication to the fullest. The Peking Opera Fu Sheng tells the story of Fu Sheng, a Confucian scholar with Chinese characteristics, who drinks all day to avoid the world when the State of Qin is unified, the legalists are in power and Li Si is jealous. In the eyes of $\mathrm{Fu}$ Sheng, poetry and wine are the same as the home, and the rulers can unify the weights and measures with the train and the book with the text, but still brew the wine of six countries, and naturally can also contain the words of a hundred schools. However, Li Si was a firm legalist who defended the way. To burn books and defeat Confucianism, Fusheng had no choice but to burn books of a hundred schools with wine. However, Fu Sheng's son, Zi Bo, did not understand Lao Zhuang's submission, and he followed Confucius and Mencius' example of "sacrificing his life for righteousness". He led Confucian scholars to encirclement the palace and remonstrates to wake up the world. Li Si came to arrest, fusheng for his son, family destruction. This deep ideal faith lies not only in the sacrifice of self, but also in the sad gall of knowing that it cannot be done. Finally, Beijing Opera also shows the sincere love between men and women. For example, in the Opera "Plum Blossom Zan", Plum blossom and Li Liangchuan express their sincere feelings to each other without knowing the hatred of their families. Later, when they learn the truth, they break their hatred and still love each other. To prove the undying constancy of the heart. Spirit of traditional virtues and internalization in the Beijing Opera tells the story of Beijing Opera, Peking Opera as the charity at the same time, the patriotism, the carrier of the traditional spirit of self-improvement to the generation after generation of people convey the spirit, to let the Chinese traditional spirit to be able to live on and continue to adhere to an unyielding, focus on patriotic struggle [7].

Like other excellent traditional Chinese cultures, Peking Opera is inclusive and has a long history. Peking Opera has absorbed some of the plays, tunes and performance methods of Kunqu opera and Qinqiang Opera, as well as folk tunes from various regions, and has cooperated with han artists. Take the best from each family. Peking Opera was also the most widely received form of opera, enjoyed by everyone from the royal family and nobles to the common people of that time. As a result, Peking Opera, which combines all the advantages of a hundred, has become the quintessence of Chinese culture $[1,5]$. Peking Opera is not only widely collected, but also combines the cultures of various regions and ethnic groups. The origin of Beijing Opera is the huizhou class, the earliest active in the south, for the qianlong emperor's birthday to Beijing. Later, it gradually developed and expanded in Beijing and became the most influential drama genre in China by integrating various kinds of operas from the north and south. Beijing Opera also shows an open and friendly attitude. In ancient times, Peking Opera was mostly performed for the Imperial family of the Qing Dynasty, whose emperors were Manchus [8]. However, its audience is not limited to one ethnic group. People of all ethnic groups love Peking Opera. The reason why Peking Opera is so well known in China is that it has been passed on from generation to generation. This long history is also due to its unique vitality and the contributions made by various famous artists to its development. 
Peking Opera not only carries Chinese culture, but also contains profound feelings of home and country. As the quintessence of Chinese culture, it will continue to develop and be loved by generations of people and passed down from generation to generation.

\section{References}

[1] Goldstein J . Drama Kings: Players and Publics in the Re-creation of Peking Opera, 1870-1937[J]. asian theatre journal, 2010, 26(2):272-273.

[2] Cai F, Peng R, Yu J. Analysis and synthesis of Peking opera facial make-ups[J]. Journal of ComputerAided Design \& Computer Graphics, 2009.

[3] Hwang M S . Peking opera : a study on the art of translating the scripts with special reference to structure and conventions /. USA: The florida State University, 1976.

[4] Zhou Y Y. On the Collection of Peking Opera Costumes and Its Value[J]. Journal of Huzhou Vocational and Technological College, 2012.

[5] Wichmann E. Listening to theatre: the aural dimension of Beijing Opera[J]. Aural Dimension of Beijing Opera, 1991.

[6] Repetto R C, Serra X. Creating a Corpus of Jingju (Beijing Opera) Music and Possibilities for Melodic Analysis [C]// 2014.

[7] Liu Z W. An Analysis to Beijing Opera from "Four Aspects"[J]. Journal of Xinghai Conservatory of Music, 2012.

[8] Thorpe A. The Soul of Beijing Opera: Theatrical Creativity and Continuity in the Changing World. By Li Ruru. Hong Kong: Hong Kong University Press, 2010. xvi, 335 pp. \$28.00 (paper).[J]. The Journal of Asian Studies, 2013. 